\title{
ANALISIS JIWA KEWIRAUSAHAAN SISWA SD NEGERI 1 WINDUJAYA KECAMATAN KEDUNGBANTENG KABUPATEN BANYUMAS
}

\author{
Lutfi Munawaroh', Kartika Chrysti.S ${ }^{2}$, Muhamad Chamdani ${ }^{3}$ \\ PGSD FKIP Sebelas Maret University \\ lutfi.muna20@gmail.com
}

Article History
accepted 01/10/2020

approved 01/11/2020 published 01/12/2020

\section{Abstract ANALYSIS OF STUDENT ENTREPRENEURIAL SKILLS OF SD NEGERI 1 WINDUJAYA KEDUNGBANTENG SUB-DISTRICT BANYUMAS REGENCY}

The implementation of entrepreneurial skills since early age is important. SD Negeri 1 Windujaya has implemented it. The study aimed to describe the student entrepreneurial skills, to describe the obstacles in fostering student entrepreneurial skills, and to analyze factors affecting the student entrepreneurial skills. The data was narration about research subjects. Data collection techniques included observation, interviews, and questionnaires. The participants were students of SDN 1 Windujaya, teachers, principal, and parents. The data validity techniques were triangulation of source and triangulation of technique. Data analysis techniques were data reduction, data presentation, and verification. The observed entrepreneurial skills were selfdirected, discipline, integrity, creativity, critical thinking, communication, confidence and collaboration. Creativity and critical thinking had not worked well. The obstacles in fostering entrepreneurial skills were students' willingness and teacher innovation in learning. The factors affecting student entrepreneurial skills were students' willingness, students' interest, school environment, and family environment. It concludes that the student entrepreneurial skills work well but creativity and critical thinking are weak.

Keywords: analysis, entrepreneurship, elementary student

\begin{abstract}
Abstrak: ANALISIS JIWA KEWIRAUSAHAAN SISWA SD NEGERI 1 WINDUJAYA KECAMATAN KEDUNGBANTENG KABUPATEN BANYUMAS. Penerapan jiwa kewirausahaan siswa sejak dini sangat penting dilakukan, di SD Negeri 1 Windujaya penerapan jiwa kewirausahaan sudah diterapkan dalam lingkungan sekolah yang didukung oleh lingkungan keluarga. Untuk mengetahui jiwa kewirausahaan siswa, peneliti tertarik untuk menganalisis jiwa kewirausahaan siswa SD Negeri 1 Windujaya. Tujuan penelitian ini yaitu mendeskripsikan jiwa kewirausahaan siswa, mendeskripsikan kendala dalam menumbuhkan jiwa kewirausahaan siswa, menganalisi faktor yang mempengaruhi jiwa kewirausahaan siswa SD Negeri 1 Windujaya. Data berupa kalimat atau narasi peneliti mengenai subjek penelitian yang diperoleh melalui suatu teknik pengumpulan data yaitu observasi, wawancara, dan angket. Partisipan penelitian ini adalah siswa SDN 1 Windujaya, guru, kepala sekolah dan orang tua siswa. Teknik uji validitas data menggunakan triangulasi sumber dan teknik. Teknik analisis data yaitu: reduksi data, penyajian data, dan verifikasi. Aspek jiwa kewirusahaan yang di amati yaitu mandiri, disiplin, jujur, kreatif, kritis, komunkatif, percaya diri dan kerja sama. Terdapat dua aspek yang belum optimal dalam menumbuhkan jiwa kewirausahaan siswa yaitu; aspek kreatif dan aspek kritis. Kesimpulan penelitian ini adalah jiwa kewirausahaan siswa sudah cukup tinggi terlihat dari beberapa aspek yang diamati sudah optimal dalam penanaman jiwa kewirausahaan siswa, hanya ada dua aspek yang belum optimal yaitu aspek kreatif dan aspek kritis.
\end{abstract}

Kata Kunci: analisis, kewirausahaan, siswa sekolah dasar 


\section{PENDAHULUAN}

Pendidikan merupakan suatu kegiatan yang diprogramkan oleh pemerintah untuk meningkatkan mutu kehidupan seseorang. Pendidikan pada bangsa Indonesia mengikuti tuntutan pada pendidikan abad ke 21 . Tuntutan pendidikan abad ke- 21 dalam dunia pendidikan memerlukan adanya tujuan pendidikan yang mengarah pada abad ke-21. Untuk memenuhi kompetensi pada pendidikan abad ke-21 pemerintah melakukan pembaharuan dari KTSP menjadi Kurikulum 2013. Menurut Mastur (2017) tema pembaharuan dan perbaikan Kurikulum 2013 yaitu menciptakan manusia Indonesia yang kreatif, inovatif dan produktif melalui pengembangan sikap (afekttif), pengetahuan (kognitif) dan keterampilan secara integratif. Dunia pendidikan harus mampu berperan aktif dalam menciptakaan tenaga kerja yang mampu bersaing dengan tenaga asing. Menurut Rachmadiyanti (2016) Pendidikan yang mampu untuk mengatasi hal tersebut salah satunya adalah pendidikan yang beroirentasi pada jiwa entrepreneurship, yaitu jiwa yang berani dan mampu menghadapi problem hidup dan memiliki jiwa kreatif untuk mengatasi masalah dan mandiri, Pendidikan kewirausahaan adalah pendidikan yang menerapkan prinsip - prinsip dan metodologi kearah pembentukan kecakapan hidup (life skill) pada siswa melalui kurikulum yang dikembangkan di sekolah. Pendidikan kewirausahaan perlu dikembangkan sejak dini untuk membentuk jiwa kewirausahaan anak, melalui pendidikan kewirausahaan dapat mencetak generasi yang memiliki jiwa kewirausahaan tinggi dengan menerapkan pendidikan kewirausahaan sejak dini.

Saat ini kewirausahaan merupakan salah satu tujuan yang ingin dicapai pada kurikulum 2013. Kurikulum 2013 ingin generasi muda mempelajari kewirausahaan sejak dini. Pendidik adalah "agen of change" yang diharapkan mampu menanamkan ciri- ciri, sifat dan watak serta jiwa kewirausahaan atau jiwa entrepreneurship bagi siswanya. Jiwa entrepreneur juga sangat diperlukan bagi seorang pendidik, karena melalui jiwa ini para pendidik akan memiliki orientasi kerja yang lebih efisien, kreatif, inovatif, produk, dan mandiri. Guru perlu menyiapkan anak usia sekolah dasar dengan berbagai strategi untuk menanamkan nilai- nilai pendidikan kewirausahaan. Guru memiliki tanggung jawab yang besar dalam membentuk karakter anak agar siap dengan tantangan kehidupan dari berbagai aspek bidang, khususnya bidang ekonomi (Rachmadyanti,2016).

. Pada kurikulum 2013 jiwa kewirausahaan dibentuk sejak dini. Kasmir (2018) bahwa jiwa kewirausahaan mendorong minat seseorang untuk mendirikan dan mengelola usaha secara profesional. Menumbuhkan jiwa kewirausahaan pada siswa sejak dini melalui pendidikan kewirausahaan agar dapat terarah menjadi wirausahawan muda yang menciptakan lapangan pekerjaan untuk mengurangi pengangguran di lingkungan sekitar. Menurut Barnawi (2012) bahwa nilai-nilai kewirausahaan yang dapat dikembangkan di sekolah yaitu : (1) mandiri, (2) kreatif, (3) berani mengambil resiko, (4) berorientasi pada tindakan, (5) kepemimpinan, (6) kerja keras, (7) jujur, (8) disiplin, (9) inovatif, (10) tanggung jawab, (11) kerja sama, (12) pantang menyerah, (13) komitmen, (14) realistis, (15) rasa ingin tahu, (16) komunikatif, dan (17) motivasi kuat untuk sukses.

Di SD Negeri 1 Windujaya penanaman kewirausahaan masih sangat rendah, materi kewirausahaan hanya diberikan pada pembelajaran saja, sehingga jiwa kewirausahaan siswa kurang untuk digali oleh guru. Cara guru mengajar masih menggunakan cara tradisional atau menggunakan ceramah dan siswa mengerjakan lembar kerja siswa, dalam nilai-nilai kewirausahaan, terdapat beberapa sikap salah satunya yaitu sikap kemandirian, sikap kemandirian siswa masih rendah hal ini ditandai dengan menyelesaikan tugas, siswa masih bergantung kepada teman untuk menyelesaikan tugasnya. Kewirausahaan pada sekolah dasar terintegrasi pada semua mata pelajaran. Hal ini dibuktikan dengan siswa menerapkan sikap kreatif, siswa dapat mengungkpkan gagasan/ide baik kepada guru maupun teman dan dapat diterapkan pada saat pembelajaran. Hal ini dibuktikan dengan siswa menyelesaikan tugas secara bekerja sama, siswa diajarkan untuk bertukar pendapat dalam bekerja sama. Selain 
menerapkan sikap kerja sama, siswa juga dapat menerapkan sikap komunikasi, ketika siswa sedang bekerja sama terlihat siswa aktif dalam mengungkapkan pendapatnya dan siswa mampu bergaul dengan orang lain.

Berdasarkan observasi di lapangan peneliti memilih salah satu sekolah yaitu SD Negeri 1 Windujaya dengan jumlah siswa sebanyak 147 siswa, dengan jumlah laki-laki 75 siswa dan perempuan sebanyak 72 siswa. Jiwa kewirausahaan kelas rendah tentu berbeda dengan kelas tinggi. Pada kelas rendah jiwa kewirausahaan masih belum optimal. Hal ini terlihat pada sikap mandiri, kerja sama, kreatif dan kritis. Siswa belum mampu untuk mengungkapkan gagasan/ide dan siswa belum mampu untuk menyelesaikan masalah dengan menggunakan strategi yang tepat. Pada kelas tinggi jiwa kewirausahaan siswa sudah cukup optimal. Hal ini terlihat pada sikap mandiri, kerjasama,disiplin,komunikasi, serta percaya diri. Siswa mampu untuk menghargai pendapat saat diskusi dan siswa mampu untuk mengerjakan tugas sendiri tanpa mencontek temannya.

Kewirausahaan penting diterapkan sejak usia dini, jika kewirausahaan tertanam sejak usia dini, dapat melahirkan wirausaha muda yang mampu membuka lapangan pekerjaan untuk mengurangi angka pengangguran di sekitarnya. Menurut Maryani (2018) "Kewirausahaan yang sering dikenal dengan sebutan entrepreneurship berasal dari bahasa Prancis yaitu entrepreneur yang diterjemahkan secara harfiah adalah perantara". Menurut Sulistyaningsih (dalam Maryani, 2018) Kewirausahaan dapat diartikan sebagai semangat perilaku dan kemampuan seseorang untuk mengambil inisiatif, kreatif dalam mengorganisir ekomoni dan mengubah sumber daya dan situasi menjasi lebih bermanfaat dan menguntungkan serta berani untuk mengambil risiko dan kegagalan dalam berwirausaha.

Menurut Sulistyowati (2016) "Kewirausahaan merupakan sifat, ciri, dan watak seseorang yang memiliki kemauan dalam mewujudkan gagasan, ide yang inovatif dan berani mengambil risiko ke dalam dunia nyata secara kreatif. dunia nyata secara kreatif. Pembelajaran kewirausahaan yang ditanamkan sejak usia dini dapat dilakukan dengan berbagai kegiatan belajar yang disesuaikan dengan kebutuhan, potensi, bakat, dan minat anak. kewirausahaan harus disertai dengan minat dan bakat anak, guru hanya memberikan fasilitas sarana dan prasarana". Jones(2010) mengatakan bahwa kewirausahaan adalah sebuah konsep yang menyediakan pengajaran disiplin yang dapat dieksplorasi dengan menggunakan pendekatan keterampilan sehingga melatih siswa untuk mengeksplore lingkungan sekitar dengan menggunakan pendekatan keterampilan.

Menurut Ruskuvaara (2013) bahwa pendidikan kewirausahaan adalah masalah pembelajaran kewirausahaan, tentang kewirausahaan dan melalui kewirausahaan. Pendidikan kewirausahaan memungkinkan perencanaan karir, menyediakan cara kewirausahaan untuk memeriksa dan melaksanakan hal-hal dan dapat digunakan dalam pengajaran dan pembelajaran. Penelitian ini akan menganalisis jiwa kewirausahaan siswa SD Negeri 1 Windujaya Kecamatan Kedungbanteng Kabupaten Banyumas yang mencakup aspek jiwa kewirausahaan, kendala dan faktor yang mempengaruhi jiwa kewirausaahan siswa. Ada beberapa aspek yang akan diamati yaitu mandiri, percaya diri, jujur, kreatif, komunikatif, kritis, kerjasama dan disiplin.

Berdasarkan latar belakang masalah yang telah dipaparkan oleh peneliti, maka dapat dipaparkan rumusan masalah sebagai berikut: (1) Bagaimana jiwa kewirausahaan siswa? (2) Adakah kendala dalam menumbuhkan jiwa kewirausahaan siswa? (3) Faktor - faktor apa saja yang mempengaruhi jiwa kewirausahaan siswa SD Negeri 1 Windujaya, Kecamatan Kedungbanteng, Kabupaten Banyumas? 


\section{METODE}

Penelitian ini merupakan penelitian kualitatif dengan tipe narasi design. Subjek penelitian ini adalah siswa SD Negeri 1 Windujaya. Penelitian ini dilaksanakan di SDN 1 Windujaya yang berlangsung dari bulan November 2019 sampai Februari 2020.

Penelitian ini mendeskripsikan dan menganalisis aspek jiwa kewirausahaan siswa SD Negeri 1 Windujaya Selain itu dalam penelitian ini peneliti akan mendeskripsikan kendala dalam menumbuhkan jiwa kewirausahaan siswa dan mendeskripsikan faktor yang mempengaruhi jiwaa kewirausahaan siswa. Subjek dalam penelitian ini adalah siswa, guru, kepala sekolah dan orang tua siswa.

Data yang diambil untuk penelitian ini adalah data kualitatif. Sumber data dalam penelitian ini terdiri dari tempat dan peristiwa, serta informan. Teknik pengumpulan data pada penelitian ini terdiri dari observasi, wawancara, dan angket. Teknik uji validitas data pada penelitian ini adalah teknik triangulasi sumber.

Teknik analisis data pada penelitian ini mengacu pada model analisis data menurut Miles dan Huberman (Sugiyono, 2014: 92-99) yang terdiri dari reduksi data, penyajian data, dan verifikasi.Tahapan penelitian ini meliputi: (1) tahap pra lapangan terdiri; (2) tahap pekerjaan lapangan; (3) tahap analisis data; (4) tahap validitas data.

\section{HASIL DAN PEMBAHASAN}

Berdasarkan hasil observasi, wawancara dan pengisian angket yang telah dilaksanakan di SDN 1 Windujaya dengan subjek siswa kelas I-V, guru kelas I-V, kepala sekolah dan orang tua siswa. Proses pembelajaran kewirausahaan masih terintegrassi dengan proses pembelajaran tematik. Proses pembelajaran kewirausahaan belum terlaksana dengan optimal. Berdasarkan pendapat di atas tentang 17 aspek kewirausahaan, peneliti memfokuskan beberapa aspek yaitu : mandiri, displin, jujur, komunikatif, kreatif, kritis, percaya diri, dan kerja sama. Berikut ini merupakan hasil penelitian tentang jiwa kewirausahaan siswa :

Tabel Hasil Penelitian Analisis Jiwa Kewirausahaan Siswa

\begin{tabular}{lll}
\hline No. & Aspek yang diamati & \multicolumn{1}{c}{ Hasil penelitian } \\
\hline 1. & Mandiri & Berdasarkan hasil penelitian bahwa \\
& persentase sikap mandiri mencapai \\
& $86 \%$ tergolong baik. Secara \\
& keseluruhana siswa mampu untuk \\
& menyelesaikan tugas secara sendiri, \\
& menyelesaikan masalah sendiri serta \\
& bisa memotivasi sendiri dalam \\
& belajar. & \\
& Berdasarkan hasil penelitian bahwa \\
& persentase sikap disiplin mencapai \\
& 85\% tergolong baik. Tingkat \\
& kedisiplinan siswa sudah tinggi dalam \\
& pembeljaran maupun dalam aturan \\
& yang berlaku. Hal ini terlihat dari hasil \\
& observasi bahwa siswa mammpu \\
& untuk mengikuti aturan yang berlaku \\
& disekolah dan mampu untuk \\
& mengerjakan tugas dengan baik. \\
\hline
\end{tabular}


Volume 8 Nomor 3 Tahun 2020

\begin{tabular}{|c|c|c|}
\hline & Jujur & $\begin{array}{l}\text { Berdasarkan hasil penelitian bahwa } \\
\text { persentase sikap jujur mencapai } 85 \% \\
\text { tergolong baik. Tingkat kejujuran } \\
\text { siswa sudah cukup baik. Siswa tidak } \\
\text { mencontek temannya dan siswa } \\
\text { mampu mengatakan } \\
\text { ketidaknyamanan dalam belajar serta } \\
\text { mampu mengatakan kesulitan } \\
\text { belajar. }\end{array}$ \\
\hline 4. & Komunikatif & $\begin{array}{l}\text { Berdasarkan hasil penelitian bahwa } \\
\text { persentase sikap komunikatif } \\
\text { mencapai } 90 \% \text { tergolong sangat baik. } \\
\text { Secara keseluruhan siswa senang } \\
\text { dalam bergaul, berbicara dan bekerja } \\
\text { sama. }\end{array}$ \\
\hline 5. & Kreatif & $\begin{array}{l}\text { Berdasarkan hasil penelitian bahwa } \\
\text { persentase sikap kreatif mencapai } \\
66 \% \text { tergolong rendah. Siswa masih } \\
\text { bingung dalam mengemukakan } \\
\text { gagasan/ide baik kepada guru } \\
\text { maupun kepada teman dan siswa } \\
\text { belum mampu mengurutkan hal-hal } \\
\text { penting dalam pembelajaran. Hal ini } \\
\text { di dukung dengan hasil observasi } \\
\text { bahwa siswa bingung dalam } \\
\text { mengemukakan gagassan/ide dan } \\
\text { siiswa juga belum mampu dalam } \\
\text { mengurutkan hal-hal penting dalam } \\
\text { pembelajaran. }\end{array}$ \\
\hline 6. & Kritis & $\begin{array}{l}\text { Berdasarkan hasil penelitian bahwa } \\
\text { persentase sikap kritis mencapai } 60 \% \\
\text { tergolong rendah. Secara } \\
\text { keseluruhan tingkat berpikir kritis } \\
\text { siswa masih rendah, siswa belum } \\
\text { mampu dalam menyelesaikan } \\
\text { masalah dengan menggunakan } \\
\text { strategi yang tepat, }\end{array}$ \\
\hline 7. & Percaya diri & $\begin{array}{l}\text { Berdasarkan hasil penelitian bahwa } \\
\text { persentase sikap komunikatif } \\
\text { mencapai } 80 \% \text { tergolong baik. } \\
\text { Secara keseluruhan tingkat percaya } \\
\text { diri siswa baik. Siswa tidak malu saat } \\
\text { di kelas maupun di lingkungan } \\
\text { sekolah, siswa berani untuk } \\
\text { mengungkapkan pendapat dan } \\
\text { berani bertanya saat pembelajaran. }\end{array}$ \\
\hline
\end{tabular}


Volume 8 Nomor 3 Tahun 2020

8. Kerja sama

\begin{tabular}{ll}
\hline 8. Kerja sama & Berdasarkan hasil penelitian bahwa \\
persentase sikap komunikatif & mencapai $80 \%$ tergolong baik. \\
& Tingkat kerja sama siswa cukup baik, \\
hampir semua siswa senang ketika & bekerja sama. Siswa juga sudah \\
mampu dalam menghargai pendapat \\
orang lain, aktif berdiskusi saat \\
pembelajaran dan aktif dalam \\
mengungkapkan pendapatnya,
\end{tabular}

Pelaksanaan pendidikan kewirausahaan sangat penting diterapkan sejak dini. $\mathrm{Hal}$ ini bertujuan untuk menanamkan jiwa kewirausahaan sejak dini yang terintegrasi pada kegiatan pembelajaran. Hal ini sesuai dengan pendapat Hananta (2015) bahwa pendidikan kewirausahaan dapat menanamkan jiwa kreatifitas dan inovasi dalam menangani masalah dan mempunyai peluang dalam berhasil. Tujuan dari penanaman kewirausahaan sejak dini yaitu untuk mengembangkan karakter kewiirausahaan, dengan pelaksanaan yang masih terintegrasi pada kegiatan pembelajaran. Pelaksanaan kewirausahaan di SD Negeri 1 Windujaya masih terintegrasi dengan kegiatan pembelajaran sehingga penanaman jiwa kewirausahaan masih kurang optimal.

Kendala dalam menumbuhkan jiwa kewirausahaan siswa yaitu kemauan dan inovasi pembelajaran, pada aspek kemauan secara keseluruhan siswa sudah cukup tinggi dalam menumbuhkan jiwa kewirausahaan, hanya terdapat beberapa aspek yang belum optimal dalam menumbuhkan jiwa kewirausahaaaan siswa yaitu aspek kreatif dan kritis. Aspek inovasi dalam pembelajaran yaitu secara keseluruhan inovasi guru dalam pembelajaran masih kurang optimal sehingga siswa cepat merasa bosan dalam pembelajaran, dan memilih mencari kesibukan lain untuk menghilangkan rasa bosan sehingga keadaan kelas kadang kurang kondusif. Perlunya bimbingan guru dalam mengggunkan media pembelajaran yang menarik sangat pnenting dilakukan untuk menghilangkan rasa bosan siswa saat pembelajaran. Hal ini sejalan dengan pendapat Setiawan, Karsinah (2016) bahwa perlunya memberikan pelatihan kepada guru sekolah dasar untuk membuat media pembelajaran yang menarik dan berbasis audiovisual, serta menanamkan nilai-nilai kewurausahaan dan pelestarian lingkungan dalam penyampaian materinya. Penanaman kewirausahaan harus memperhatikan aspek keterampilan untuk mengembangkan jiwa kewirausahan siswa. Hal ini sejalan dengan pendapat Jusoh (2012) bahwa penanaman pendidikan kewirausahaan harus mempertimbangkan aspek keterampilan dan tidak hanya menekankan pada pembelajaran teoretis. Guru harus mampu dalam mengembangkan aspek pengetahuan, keterampilan dan sikap dalam upaya meningkatkan jiwa kewirausahaan siswa sehingga mampu berkembang menjadi wirausaha yang memiliki jiwa kewirausahaan yang tinggi.

Faktor-faktor yang mempengaruhi jiwa kewirausahaan siswa: (a) Kemauan, secara keseluruhan tingkat kemauan siswa dalam berwirausaha sudah cukup tinggi, jika siswa mempunyai kemauan untuk berwirausaha maka siswa akan melakukan suatu kegiatan yang mendukung dalam berkewirausahan meskipun melakukan kegiatan dengan pura-pura ataupun dalam kenyatan. Hal ini sejalan dengan pendapat Prasetyaningsih (2016) bahwa Dengan adanya kemauan anak akan mencoba berwirausaha baik dalam kegiatan yang hanya pura-pura ataupun dalam kenyataan. Tetapi ada beberapa aspek yang belum terpenuhi atau belum muncul karena ada beberapa yang mempengaruhi salah satunya yaitu inovasi guru dalam pembelajaran. (b) Ketertarikan, tingkat ketertarikan siswa cukup tinggi dalam kewirausahaan dengan beberapa aspek yang terpenuhi sudah bisa mengambarkan rasa ketertarikan siswa dalam penanaman jiwa kewirausahaan siswa; ; (c) Lingkungan sekolah, lingkungn 
sekolah sangat mempengaruhi penanaman jiwa kewirausahaan sejak dini, lingkungan sekolah yang baik yaitu lingkungan sekolah yang didukung dengan fasilitas yang memadai sehingga jiwa kewirausahaan siswa dapat tumbuh dengan baik. Hal ini sejalan dengan pendapat Rachmayanti(2016) bahwa berbagai faktor yang mempengaruhi minat anak untuk berwirausaha tersebut, maka sekolah sebagai lembaga formal wajib membimbing siswa, mengarahkan berbagai faktor yang mempengaruhi minat anak berwirausaha tersebut, maka sekolah sebagai lembaga formal wajib membimbing siswa, mengarahkan, dan menanamkan pendidikan kewirausahaan sejak dini. Melalui pembelajaran sehari hari, guru dapat memahami karakter anak, minat anak, dan potensi anak. Jika mereka memiliki keinginan untuk berwirausaha kelak, maka sebagai guru harus memotivasi cita- cita mereka tesebut. Tidak bisa dipungkiri, mungkin tidak semua siswa senang berwirausaha, namun paling tidak sekolah memberikan fasilitas dan bimbingan guna menyalurkan nilai- nilai kebaikan dari memiliki jiwa entreprenurship. Sesuai pembahasan sebelumnya, karakter- karakter wirausaha yang dapat ditanamkan kepada siswa sekolah dasar dapat dimulai dari karakter- karakter baik, seperti, kreatif, mandiri, leadership, mampu memecahkann masalah, tidak mudah putus asa, mampu mengelola uang, dan dapat berinteraksi dengan (d) Lingkungan keluarga mempunyai peran penting dalam penanaman jiwa kewirausahaan siswa. Penanaman jiwa kewirausahaan siswa juga di terapkan di rumah, orang tua dapat menerapkan beberapa aspek yang dapat mengembangkan jiwa kewirausahaan siswa, seperti pada aspek jujur, di rumah siswa diajarkan jujur dalam segala hal. Rasa percaya diri dilingkungan rumah maupun di lingkungan masyarakat, siswa mudah berbaur dengan orang lain dan siswa senang jika membantu orang tua,

\section{SIMPULAN}

Berdasarkan hasil penelitian dan pembahasan yang telah diuraikan, maka simpulan dari penelitian ini adalah: (1) Aspek jiwa kewirausahaan siswa yang dapat diamati di SD Negeri 1 Windujaya yaitu mandiri, disiplin, jujur, komunikatif, kreatif, kritis, percaya diri, dan kerja sama. Secara keseluruhan jiwa kewirausahaan siswa sudah optimal dan penanaman jiwa kewirausahaan berkembang dengan baik hanya ada beberapa aspek yang belum terpenuhi secara optimal. Aspek yang belum optimal dalam penanaman jiwa kewirausahaan yaitu kreatif, dan kritis. (2) Kendala dalam penanaman jiwa kewirausahaan siswa yaitu masih terdapat beberapa aspek yang belum optimal dalam penanaman jiwa kewirausahaan siswa, aspek yang belum optimal yaitu kreatif, kritis dan kerja sama. Pada aspek kreatif siswa sudah cukup bagus tetapi masih kurang dikembangkan oleh guru, inovasi pembelajaran jika diterapkan secara optimal dapat mengembangkan kreatif siswa. Guru harus menerapkan inovasi pembelajaran secara optimal sehingga siswa tidak merasa bosan dalam pembelajaran dan memilih mencari kesibukan lain untuk menghilangkan rasa bosan. (3) Faktor- faktor yang mempengaruhi jiwa kewirausahaan siswa: (a) Kemauan, Tingkat kemauan siswa dalam berkewirausahaan akan tinggi jika siswa melakukan suatu kegiatan yang dapat mendukung dalam berkewirausahaan, dengan adanya kemauan maka siswa akan mencoba melakukan suatu tindakan yang dapat mendukung dalam penanaman jiwa kewirusahaan; (b) Ketertarikan, Rasa tertarik siswa dalam berwirausaha bisa di lihat dari beberapa aspek seperti mandiri, disiplin, jujur, komunikatif, kreatif, kritis, percaya diri, dan kerja sama. Jika beberapa aspek dapat terpenuhi maka siswa mempunyai rasa tertarik pada wirausaha; (c) Lingkungan sekolah, lingkungan sekolah sangat mempengaruhi penanaman jiwa kewirausahaan sejak dini, lingkungan sekolah yang mendukung dengan fasilitas yang baik maka jiwa kewirausahaan siswa dapat tumbuh dengan baik; (d) Lingkungan keluarga, lingkungan keluarga juga mempunyai peran penting dalam penanaman jiwa kewirausahaan siswa. Orang tua merupakan guru pertama dengan penuh kasih sayang membimbing dan banyak memberikan pengaruh 
warna kepribadian anak sehingga keinginan yang besar dari anak menjadi mudah diwujudkan

Berdasarkan uraian hasil penelitian, implikasi dari penelitian ini yaitu: (1) bagi sekolah, penelitian ini dapat dijadikan dasar untuk melakukan penanaman jiwa kewirausahaan siswa agar dapat optimal; (2) guru sebagai pelaksana pembelajaran dapat melaksanakan inovasi pembelajaran dan pemanfaatan media pembelajaran agar penanaman jiwa kewirausahaan siswa dapat di tanamkan secara optimal (3) siswa sebagai pelaksana penanaman jiwa kewirausahaan dapat dijadikan dasar untuk lebih memahami informasi yangs diberikan guru dalam mengembangkan jiwa kewirausahaan sejak dini.

\section{DAFTAR PUSTAKA}

Barnawi, Mohammad Arifin.2012.School Preneurship.Jogjakarta: Ar-Ruzz Media Hananta, Arif Tri.(2015). Studi Eksplorasi Pendidikan Kewirausahaan di Sekolah Dasar Unggulan Aisiyah Bantul. Jurnal Pendidikan Guru Sekolah Dasar Edisi 16 Tahun ke IV September 2015

Jones, Brian.2010. Enterprise education as pedagogy. Education $p$ Training Vol. 52 No. 1, 2010 pp. 7-19.

Jusoh, Rosnani.2012. Effects of teachers" readiness in teaching and learning of entrepreneurship education in primary schools. International Interdisciplinary Journal of Education - August, 2012, Volume 1, Issue 7.

Kasmir.2018.Kewirausahaan.Depok: PT. RajaGrafindo Persada

Maryani, Leni, Mohammad Nurhadi, Nurul Fazriyah.2018. Menumbuhkan Kewirausahaan Pada Anak Sekolah Dasar Melalui Pembelajaran Tematik. Seminar Nasional Pendidikan Dasar (Sepeda) Pgsd Fkip Universitas Pasundan Isbn : 9 - 789798 - 793974 Bandung, 15 November 2018.

Mastur.2017.Implementasi Kurikulum 2013 Dalam Pelaksanaan Pembelajaran di Smp. Jurnal Inovasi Teknologi Pendidikan Volume 4, No 1, April 2017 (50-64)

Prasetyaningsih, Asri.2016. Membentuk Jiwa Kewirausahaan Pada Anak Usia Dini Melalui Kegiatan "Market Day" Jurnal Program Studi PGRA ISSN (Print): 2540-8801; ISSN (Online):2528-083X Volume 2 Nomor 2 Juli 2016.

Rachmadiyanti, Putri, Vicky Dwi Wicaksono. 2016. Pendidikan Kewirausahaan Bagi Anak Usia Sekolah Dasar. Prosiding Seminar Nasional Pendidikan

Ruskuvaara, Elena.2013. Teachers implementing entrepreneurship education: classroom practices. Education p Training Vol. 55 No. 2, 2013 pp. 204-216.

Setiawan, Avi Budi \& Karsinah.2016. Recharging Metode Pembelajaran Kewirausahaan Berbasis Multimedia Untuk Guru Sd Di Desa Tieng Wonosobo. Jurnal ABDIMAS Vol. 20 No. 2, Desember 2016

Sugiyono. (2014). Metode Pesnelitian Kuantitatif, Kualitatif, R\&D. Bandung: Alfabeta 